\title{
On Neurotheology? Why Engage Empirical Studies on Theological Concepts
}

\author{
Michael Mookie C. Manalili \\ Boston College School of Theology and Ministry (Brighton, MA) \\ Boston College School of Social Work (Chestnut Hill, MA)
}

\begin{abstract}
Neurotheology can open new spaces of exploration and synthesis for human understanding. In his systematic book, Neurotheology (2018), Andrew Newberg compiles research of science that touches upon the sacred, making a strong case for an approach open to both neuro- and -theology. The following paper deals with the insights, methodology, and implications of this multidisciplinary approach. The first portion defines 'neurotheology' and its current scope for research. The second portion argues for the benefit of this systematic approach, which utilizes the scientific method and Hegelian sublation. The final portion explores the implications for humanity and for epistemology, particularly in the post-modern, postreligious milieu and for science as an emerging amicus theologiae. The hope of this project is to engage our 'big questions' once more in their complexity - to curiously explore experiences and creation, in order to peek into the efficacious Mystery we call God.
\end{abstract}

\section{Text}

A flash of insight. A moment of clarity. A sense of awareness of the reality of something more. These phrases attempt to capture traces of a spiritual experience - moments of perceptions into the reality of something beyond oneself, whether triggered through liturgies, in meditative states, or even during nature walks. Human beings seem to have a capacity for perceiving complex phenomena; indeed, one can imagine the questions that arise due to these curious experiences. Perhaps, the very forerunner of humanity encountered phenomena akin to these. Reflecting upon the first person, Michelangelo represents The Creation of Adam in a thought-provoking manner: Adam, already existing, is depicted as limply grasping for something beyond himself; God is 


\section{MANALILI: ON NEUROTHEOLOGY?}

portrayed as reaching out with clear intent to bestow something to humanity. ${ }^{1}$ Upon closer inspection, the heavenly hosts and the pink veil around God reveal a strange pattern. Reflecting upon this image, neuroscientist Frank Meshberger noticed the resemblance of this image of God to the anatomical human brain. ${ }^{2}$ Meshberger argues that creation here refers to the bestowal of a complex brain, allowing us the capacity and range to be 'fully human. ${ }^{3}$ Striking a similar nerve, neuroscientist and scholar Andrew Newberg proposes that we explore this insight further: "Perhaps, by finding a new and integrated way of using the best of science as well as religion, we might have an opportunity to better answer some of the truly 'big questions' that have faced humanity since its dawn."

This paper argues for the importance of empirical studies in conversation with theological concepts. Although this formulation is vague, this attempts to keep the expansive scope of the project, including but not limited to discourse between different academic disciplines, to refining theological concepts through unfolding discovery, and to answer novel questions that lead into even more questions into the heart of Mystery. The first section defines what: the principles of 'neurotheology,' according to Newberg. The second section outlines how: exploring 'big questions' through a multidisciplinary framework. The final section reflects on why: the implications of neurotheology for humanity and for epistemology. For the purpose of this paper, I will focus on the methodology and its implications, eschewing technical scientific discussions for

\footnotetext{
${ }^{1}$ Michelangelo, The Creation of Adam, 1512, Fresco, $280 \times 570 \mathrm{~cm}$, Sistine Chapel, Vatican City.

${ }^{2}$ Frank Lynn Meshberger, “An Interpretation of Michelangelo's Creation of Adam Based on Neuroanatomy," JAMA. 264 (14) (1990): 1837-41.

${ }^{3}$ The term 'fully human' here shares the vision of the personhood found in Sen and Nussbaum's 'capability approach.' This is not intended to argue for ableism, in which human persons below a certain threshold for cognitive capacity and other ability is not deemed 'fully human.' Rather, this insight points to the way in which the human brain allows for experiences such as "senses, imagination, and thought" - and even "play" - pointing to the complexity and richness that our embodied structures allow for.

${ }^{4}$ Andrew Newberg, Neurotheology: How Science Can Enlighten Us About Spirituality (New York: Columbia University Press, 2018), 40.
} 
the time being. The neurotheological project hopes to reopen 'big questions' once more - to reopen our theological epistemology through a posture of collaboration, curiosity, and humility. Like the first person's yearning to touch upon the edge of Truth, perhaps we can reconnect the severed boundaries of these fields to better understand this world, each other, and the Mystery we call God.

\section{What - Principles of Neurotheology}

In order to engage in critical discourse on this multidisciplinary approach, we will briefly i.) define 'neurotheology' and ii.) its current scope for research on embodied experience.

i.) According to Newberg, neurotheology is the multidisciplinary exploration of religious, spiritual, and mystical experiences (RSME's) and their correlation with the brain. ${ }^{5} \mathrm{He}$ argues against the false dichotomies between science and technology on one side and religion and spirituality on the other, instead calling for an empirical dialogical approach where these forces combine in specific yet complex ways. Both "neuro" and "theology" are allowed to remain expansive in nature. Thus, neurotheology does not shy away from utilizing the breadth and depth of "anthropology, cognitive neuroscience, neurology, psychology, and sociology," as well as "beliefs, myths, religion, rituals, spiritual practices, spirituality, and theology." Guiding these explorations, its four foundational goals concern improving the following: understanding of the human mind and brain, understanding of religion and theology, the human condition in the context of health and well-being, and the human condition in the context of religion and spirituality. ${ }^{7}$

${ }^{5}$ Lisa J. Miller, ed., The Oxford Handbook of Psychology and Spirituality (New York: Oxford University Press, 2012), 500:: "The past decade has seen the emergence of the neuroscience of spirituality. The central objective of this domain of research is to use neuroscience methods (e.g., brain imaging, stimulation, psychopharmacological, electrophysiological recordings) to explore the neural mechanism meditating religious, spiritual, and mystical experiences (RSMEs). These experiences relate to a fundamental dimension of human experience and are frequently reported across cultures. Regarding this issue, it is important to fully appreciate that elucidating the neural substrates of RSMEs does not diminish or depreciate their meaning and value."

${ }^{6}$ Newberg, Neurotheology, 6.

${ }^{7}$ Newberg, 41. 
However, the original overarching telos for its project is an epistemic one: to deeply explore "the nature of reality and how humans perceive that reality."

ii.) Currently, neurotheology analyzes the wide array of RSME's through an embodied (particularly, an enbrained) perspective. Pointing out that neural activity is present even during the state of deep unconsciousness in coma, Newberg notes that everything we do and experience affects the brain. "Every facet of reality has an impact on our brain in one form or another, which in turn helps us to interpret what reality actually is." ${ }^{\prime 9}$ Recent advances in neuroimaging have allowed us glimpses into the living brain. Once a black-box only to be opened in death, the living brain can now be observed in its rewiring, dynamism, and activity. For example, Newberg and his student conducted preliminary studies on the effects of praying the Rosary. They compared two groups, one praying the rosary and one watching a religious video; they observed the following:

"The result was that those students praying the Rosary had significantly less anxiety compared to the video group. Such a result could have implications for neurotheology since the parasympathetic nervous system likely was activated, and perhaps activity in structures such as the amygdala was reduced. This simple study, like many more robustly designed studies, provides an important piece to the overall neurotheology puzzle." 10

Highlighting different theological concepts in each chapter, Newberg argues that 'big questions' can be explored from a hermeneutic of wonder: big questions regarding consciousness, free will, meditation, ritual practice, mystical ecstasy, and the like. From this hermeneutic posture of finding surprise and awe in creation, the way towards a multidisciplinary framework becomes possible.

\section{How - Exploring Multidisciplinary 'Big Questions'}

Let us now discuss how this systematic framework can enrich theological inquiry: through both i.) the scientific method and ii.) the dialectic approach.

\footnotetext{
${ }^{8}$ Newberg, 44.

${ }^{9}$ Newberg, 17.

${ }^{10}$ Newberg, 220.
} 


\section{MANALILI: ON NEUROTHEOLOGY?}

i.) First, contrary to the cold, rigid quest for truth, the scientific method's empirical and observational approach can foster humility, curiosity, and acceptance. The scientific method may be tempted to reduce complex phenomena merely to their physical substrates to analyze and to control. However, this shallow wading into the depth of Mystery need not be the only way that the scientific method is utilized. Making a parallel with the quest for Truth in another discipline, the father of empiricism Francis Bacon reminds us that "a little philosophy inclineth man's mind to atheism; but depth in philosophy bringeth men's minds about to religion." 11 Bacon notes that proper investigation and inquiry can leave humanity dumbfounded at the complexity of the world.

Curious minds utilized this method to continue unpacking the efficacious mysteries that govern our universe, leading us to better participation in the dance of it all. St. Thomas Aquinas, Galileo Galilei, Gregor Mendel, Werner Heisenberg, Pierre Teilhard de Chardin, and many nameless others have contributed to the repository of empirical knowledge, triggered by their wonder and awe at creation. Currently, the modern scientific method resembles some variation of the following form: (a) make observation, (b) ask question, (c) form hypothesis, (d) test prediction, and (e) improve iteration. The methodology explicitly begins with humility (observation) and curiosity (questioning). Rather than assume that the answer (hypothesis) is static and definitive, the scientist listens to the unfolding answers embedded in creation (prediction and iteration). Although this is important for neurotheology, the scientific method can also improve theological pedagogy. For example, the Catechesis of the Good Shepherd proposed by biblical scholar Sofia Cavalletti utilizes experience-based activities to groom the child's religious potential. ${ }^{12}$ Adding a neurotheological aspect to Cavalletti's model, findings in brain development can give rise to

\footnotetext{
${ }^{11}$ Francis Bacon, “Of Atheism.,” in Essays, Civil and Moral (New York: The Harvard Classics, 1909), https://www.bartleby.com/3/1/16.html.

12 Sofia Cavalletti, The Religious Potential of the Child: Experiencing Scripture and Liturgy With Young Children, trans. Patricia M. Coulter and Julie M. Coulter (Chicago: Liturgy Training Publications, 1992).
} 


\section{MANALILI: ON NEUROTHEOLOGY?}

theological activities that nurture the appropriate mental and spiritual capabilities of each age group. Thus, we can meet the flock where they actually are - instead of attempting to find the flock in our expectations, where they may not be present and which may not be grounded in reality.

ii.) Additionally, the dialectic approach plays a beneficially progressive - albeit seemingly dangerous role - in neurotheology. Echoing the words of philosopher and theologian Emmanuel Falque, our lived experiences unveil the dance of cosmos and chaos [Tohu-wa-Bohu], the forces at play that are both within-reason and beyond-reason. ${ }^{13}$ In order to study the complexity of our world, our systematic thought must be pliable enough not to break under the burden of paradoxes and contradictions. According to a neurotheological perspective, "scholars should take a hybrid approach that would somehow strive to incorporate the best of what science can offer and the best of what religion and theology can offer." ${ }^{\prime 14}$ Newberg proposes a dangerous gamble of healthy skepticism, as we dive into the complexity of knowing what is really real. "We never know for sure if our ideas are accurate. Our ideas about God and religion may very well reflect the true nature of the universe, or they might be completely delusional." 15

This uncertainty could make any theologian uneasy, as it concerns the very axiom of God's existence; however, Newberg calls for a dialectic approach that can sharpen this very belief. This resembles the process popularized by philosopher Georg Wilhelm Friedrich Hegel - the process of sublation [aufheben]. According to Hegel, this process passes through three moments: (1) fixity and understanding, (2) dialectic and instability, and (3) speculation and unity. ${ }^{16}$ The key here is in the act 'to sublate,' which carries the double meaning of the German aufheben - to negate and to

${ }^{13}$ Emmanuel Falque, "Philosophy to Its Limits," in The Wedding Feast of the Lamb (New York: Fordham University Press, 2016), 11-30.

${ }^{14}$ Newberg, Neurotheology, 11.

${ }^{15}$ Newberg, 283.

${ }^{16}$ Georg Wilhelm Friedrich Hegel, "Logic Further Defined and Divided," in Encyclopedia of Philosophical Sciences, trans. by William Wallace (New York: Oxford University Press, 1892), §79-82. 


\section{MANALILI: ON NEUROTHEOLOGY?}

preserve concurrently. ${ }^{17}$ Contrary to simplistic reductionism or the half-and-half approach, later moments of sublation subsume earlier moments, both replacing and preserving earlier concepts. For neurotheology, in particular, observation of the brain can trigger sublation. There is something that happens subjectively and objectively; there are indeed changes in the brain during RSME's. Thus, this reality refines previously held axioms of how RSME's affect us somatically, regardless if the starting point is theism or atheism. Through sublation, concepts of RSME's could arise that capture the complexity of these phenomena, thus pushing the boundaries of previously held beliefs.

Newberg does point out an important epistemic point: "whether or not we believe in God has no bearing on whether God actually exists." ${ }^{18}$ As theologians in this process, we must allow the Truth to speak for itself - and to refine our ideas if they are lacking. We must take a humble, trembling step towards the boundary of our particular beliefs, in order for them to give way to a more comprehensive understanding of reality.

\section{Why - Implications for Humanity and for Epistemology}

This orientation towards a multidisciplinary approach is not merely a nice, novel thought - it is becoming a necessity for theological survival. In the western post-religious milieu, i) this multidisciplinary approach allows the theological voice to be heard by others once more. Furthermore, ii) this multidisciplinary dialogue guards against the limitations of each field - giving way to a mutual friendship in the pursuit of Truth.

i) By observing the common tongue of this generation, the neurotheological approach reopens space for the theological voice to speak. According to a Cambridge study within the past

${ }^{17}$ Stanford Encyclopedia of Philosophy Online, "Hegel's Dialectics," by Julie E. Maybee, first published Fri Jun 3, 2016, https://plato.stanford.edu/entries/hegel-dialectics/

${ }^{18}$ Newberg, Neurotheology, 283. 


\section{MANALILI: ON NEUROTHEOLOGY?}

decade, about 20 percent of people in the U.S. report being religiously unaffiliated. ${ }^{19}$ The emerging generation is a disillusioned, skeptical group. However, the yearning for 'big questions' has not been erased from our hearts. Twenty years ago, approximately forty research articles on meditation were published; by 2016, the numbers increased to approximately 450 research articles. ${ }^{20}$ Even though religiosity is declining, the thirst for something more has remained. At the dawn of the early Church, philosophy was the primary tongue of many and played an honored role as ancilla theologiae - or handmaid of theology. Our beliefs, liturgies, and traditions danced into incarnation through philosophically grounded councils, dialogues, and 'summas' across the ages. Now, it is apparent that science holds this authoritative voice in modern thought. By translating our tradition not only into different languages but towards different disciplines, the treasures of our theological tradition can reach the deaf ears of those beyond the boundaries of religious affiliation.

ii) Dialogue is not only beneficial for encounter but also for mutual growth: proper dialogue guards against limitations of each discipline ipsa. The fields may be tempted to voraciously consume each other or to violently wield their closed 'truth' as weapons. Proper dialogue can redress these harms; dialectic iteration can help the disciplines become better, more comprehensive versions of themselves. With respect to theology, the sciences can guard against the triumphalism that has perpetuated abuse. For example, dialogue with neuroscience can help sharpen our doctrine on anthropology, which in turn will affect the psychological grounding of our clerical formation. With respect to the sciences, theology can guard against the reductionism rampant in psychology. Although neural mechanisms provide objective markers, theological reflection reminds us that loving one another is more than mere chemicals released in the brain. Theology reminds science

\footnotetext{
${ }^{19}$ Phil Zuckerman, "Atheism: Contemporary Numbers and Patterns," in The Cambridge Companion to Atheism, ed. Michael Martin (New York: Cambridge University Press, 2007), 47-68.

${ }^{20}$ Newberg, Neurotheology, 219.
} 


\section{MANALILI: ON NEUROTHEOLOGY?}

not to reduce the beauty of the whole painting to paper, pigments, and brushstrokes, so to speak like the irreducible wonder and awe bound in The Creation of Adam.

Indeed, the neurotheological approach highlights a way in which the two fields of science and theology can speak respectfully and yet issue challenges of growth. Healthy critiques can be made on either side, slowly progressing human understanding towards a more holistic and comprehensive epistemology. In the project of neurotheology, the sciences can play a role not only as an ancilla theologiae but an amicus theologiae - a friend of theology, that encourages us to listen to the chaotic and cosmic symphony of the Creator woven into the very fabric of creation.

\section{Concluding Reflection:}

Why are we here? What is our purpose? How do I know what is really real? Perhaps, these were the 'big questions' asked by the forerunner of humanity while experiencing a spiritual phenomenon - these questions which still echo in the hearts of many. Following the predictions of psychiatrist and Shoah-survivor Viktor Emil Frankl, ${ }^{21}$ Newberg notes that "many people who consider themselves atheists or agnostics continue to search for meaning and purpose in life."22 “[And] while particular philosophical or theological questions won't go away, neurotheology may bring a new perspective..." ${ }^{23}$ Recalling the etymological roots of the term religion [religare], may theologians be willing to reconnect others to the eternal perichoretical dance of tension: experience and embodiment, questions and answers, humanity and divinity, mystery and truth. Like hands

\footnotetext{
21، Among 7,948 students at 48 colleges, only 16 percent said their first goal was 'making a lot of money.' Seventy-eight percent of the students, however, checked 'finding a purpose and meaning to my life.... Let me just quote from a letter I recently received from a young American student: 'I am a 22-year-old with degree, car, security and the availability of more sex and power than I need. Now - I have only to explain to myself what it all means.", Viktor Emil Frankl, Man's Search for Ultimate Meaning (New York: Barnes and Noble, 2000), 86; 93.

${ }^{22}$ Newberg, Neurotheology, 281.

${ }^{23}$ Newberg, 285.
} 


\section{MANALILI: ON NEUROTHEOLOGY?}

limply reaching for Truth that lie just outside of our grasp, may we be open to embracing the complexity of the ineffable Mystery - Who is always revealing something more. 


\section{MANALILI: ON NEUROTHEOLOGY?}

\section{Bibliography}

Anastasi, Matthew W. and Andrew Newberg. "A Preliminary Study of the Acute Effects of Religious Ritual on Anxiety." Journal of Alternative and Complementary Medicine 14 (2) (2008): 163-165.

Bacon, Francis. "Of Atheism.” In Essays, Civil and Moral. New York: The Harvard Classics, 1909. https://www.bartleby.com/3/1/16.html.

Cavalletti, Sofia. The Religious Potential of the Child: Experiencing Scripture and Liturgy With Young Children. Translated by Patricia M. Coulter and Julie M. Coulter. Chicago: Liturgy Training Publications, 1992.

Falque, Emmanuel. The Wedding Feast of the Lamb: Eros, the Body, and the Eucharist. Translated by George Hughes. New York: Fordham University Press, 2016.

Frankl, Viktor Emil. Man's Search for Ultimate Meaning. New York: Barnes and Noble, 2000.

Hegel, Georg Wilhelm Friedrich. "Logic Further Defined and Divided." In Encyclopedia of Philosophical Sciences. Translated by William Wallace, §79-82. New York: Oxford University Press, 1892.

Meshberger, Frank Lynn. “An Interpretation of Michelangelo’s Creation of Adam Based on Neuroanatomy.” JAMA. 264 (14) (1990): 1837-41.

Michelangelo. The Creation of Adam. 1512. Fresco, 280 x $570 \mathrm{~cm}$. Sistine Chapel, Vatican City.

Miller, Lisa J., ed. The Oxford Handbook of Psychology and Spirituality. New York: Oxford University Press, 2012.

Newberg, Andrew. Neurotheology: How Science Can Enlighten Us About Spirituality. New York: Columbia University Press, 2018.

Nussbaum, Martha C. Creating Capabilities: The Human Development Approach. Cambridge, MA: The Belknap Press of Harvard University Press, 2011.

Zuckerman, Phil. "Atheism: Contemporary Numbers and Patterns." In The Cambridge Companion to Atheism. Edited by Michael Martin, 47-68. New York: Cambridge University Press, 2007. 